\title{
ARSITEKTUR MELAYU: RUMAH MELAYU LONTIAK SUKU MAJO KAMPAR
}

\author{
Gun Faisal \\ Program Studi Arsitektur Universitas Riau, Indonesia \\ gunfaisal@eng.unri.ac.id
}

\begin{abstract}
Abstrak
Arsitektur melayu memiliki tipologi yang sangat banyak, diantaranya rumah melayu Limas, rumah Lontiak, rumah Begonjong, rumah beratap Layar dan Bersayap, rumah Melayu Peranakan (campuran etnis China), serta beberapa tipikal rumah melayu lainnya. Selain memiliki 4 (empat) ruangan yaitu selasar, rumah induk, telo dan penanggah, rumah melayu juga memiliki ornamen yang terdapat pada atap lisplank dan dinding serta tiang rumah. Salah satu rumah tradisional yang ada di kabupaten Kampar yaitu Rumah Lontiok (Lentik) Melayu Majo. Tulisan ini mengidentifikasi dan mendokumentasikan rumah ini sebagai salah satu bangunan melayu yang perlu dijaga dan dilestarikan. Metode penelitian kualitatif dengan pendekatan studi kasus digunakan dalam penelitian ini dikarenakan objek penelitian yang sudah hilang dimakan usia. Teori tentang arsitektur Melayu dan ornamen bangunan Melayu sebagai background knowledge dengan didukung informasi yang diperoleh dari literatur dan data dilapangan serta pelaku kegiatan dalam lingkup penelitian. Pengolahan dan analisis data dilanjutkan dengan mengevaluasi dan membuat sketsa dan penggambaran ulang, kemudian diakhiri dengan penyusunan hasil temuan lapangan. Secara umum rumah ini dibagi kedalam 2 (dua) masa bangunan, bagian pertama yaitu rumah induk, dan yang kedua yaitu dapur, terdapat penghubung antara rumah induk dan dapur. Rumah melayu Majo merupakan bangunan bertipologi panggung dengan ciri khas atap Lontiak. Ornamen yang pertama kali terlihat pada rumah ini adalah Selembayung atau Tanduk Buang, terdapat pula ornamen seperti tombak terhunus yang disebut tombaktombak begitu juga dengan sayap layang-layang yang terletak pada keempat sudut atap. Bermacam jenis ukiran juga terdapat pada setiap sudut bangunan ini.
\end{abstract}

Kata-kata Kunci: Arsitektur Melayu, Kampar, Riau, Rumah Lontiak, Ukiran

\section{MALAY ARCHITECTURE: IDENTIFICATION MALAY LONTIAK HOUSE OF KAMPAR MAJO TRIBE}

\begin{abstract}
Malay architecture has a lot of typologies in roof forms, such as Limas, Lontiak, Begonjong, Layar and Sayap, Peranakan (a mixture of ethnic Chinese), and several other typical Malay houses. One of the traditional houses in Kampar regency is the Lontiok (Lentik) Melayu Majo house which was built involving the wider community and traditional ceremonies. This paper identifies and documents this house as one of the Malay buildings that need to be preserved. The research method used is a qualitative research method with a case study approach. The theory of Malay architecture and ornaments as background knowledge is supported by information obtained from the literature, field data, and activity actors within the scope of research. Processing and analysis data is continued by evaluating, sketching, and re-drawing, then ending with the preparation of field findings. In general, this house is divided into 2 (two) building part, the first line is the main house, and the second building mass is the kitchen, there is a connection between the main house and the kitchen. Majo Melayu House is a stage building with the characteristic of Lontiak roof. The ornaments that were first seen in this house is Selembayung or Tanduk Buang; there were also ornaments such as unsheathed spears called Tombak-tombak and Sayap Layang-layang on the four corners of the roof. Various types of carvings are found in every segment of this building.
\end{abstract}

Keywords: Malay Architecture, Kampar, Riau, Lontiak House, Carving 


\section{Pendahuluan: Keberadaan Rumah Melayu}

Arsitektur melayu memiliki tipologi yang sangat banyak, diantaranya rumah melayu Limas di Pekanbaru, rumah Lontiak di Kampar, rumah Begonjong di Gunung Toar, rumah beratap Layar dan Bersayap di Sentajo, rumah Melayu Peranakan (campuran etnis China) di Bagan Siapiapi dan Selat Panjang, serta beberapa tipikal rumah melayu di daerah lainnya. Firzal (2015) mengatakan untuk mengidentifikasi rumah Melayu terdapat tiga ciri fisik di dalam cara konstruksinya, yaitu: fakta bahwa rumah tersebut berbentuk panggung, bentuk atap pelana, dan finishing atap dengan gablefinials. Selain ciri tersebut, rumah melayu juga memiliki ornamen dan ragam hias yang kaya, bentukan ukiran yang sangat indah, motif-motif yang tidak hanya sebatas ukiran, namun memiliki filosofi dan makna yang dalam. Arsitektur Melayu merupakan aset karya arsitektur tradisional nusantara, sebagai salah satu bagian esensial dan salah satu khazanah serta warisan yang perlu digali secara mendalam (Zain dan Fajar, 2014).

Rumah bukan saja sebagai tempat tinggal di mana kegiatan kehidupan dilakukan dengan sebaik-baiknya, tetapi juga menjadi lambang kesempurnaan hidup. Dalam ungkapan disebutkan rumah merupakan "Cahaya Hidup di Bumi, Tempat Beradat Berketurunan, Tempat Berlabuh Kaum Kerabat, Tempat Singgah Dagang Lalu, Hutang Orangtua kepada anaknya” (Efendi, 2007).

Kampar merupakan wilayah pemukiman Melayu. Adat istidat dan kebudayaan yang ada di Kampar masih bisa dikatakan masih kental, baik dari tingkah laku, penggunaan bahasa Melayu dengn dialek yang khas, pakaian tradisional, yang sampai saat ini masih tetap dilestarikan oleh masyarakat setempat. Rumah Lontiak Melayu Majo merupakan salah satu bangunan tradisional yang ada di kabupaten Kampar. Rumah ini dibangun dengan proses panjang yang melibatkan masyarakat lokal serta dengan penggunaan upacara adat. Rumah Lontiok yang berada di Desa Sipungguk ini telah berusia puluhan tahun, rumah Melayu ini menampilkan daya tarik seni arsitektur yang mencerminkan budaya Melayu dan Islam. Rumah lontiak juga disebut dengan Rumah Pencalang yang bermakna sebagai rumah adat dan atapnya berbentuk melengkung.

Keberadaan rumah lontiak di Bangkinang Seberang cukup banyak. Hal ini tidak dipungkiri karena Bangkinang Seberang merupakan salah satu pemukiman penduduk Melayu asli di kabupaten Kampar. Pemukiman ini tepat berada di pinggiran sungai Kampar, yang mana sungai Kampar merupakan urat nadi perekonomian, baik sebgai jalur transportasi maupun sebagai sumber penghidupan. Dewasa ini keberadaan rumah lontiak sudah mulai hilang, bangunan tradisional mulai ditinggalkan dan sudah banyak yang rusak. Salah satu rumah Lontik yang masih bertahan yaitu Rumah Lontiak Melayu Majo, selain masih ditempati, rumah Lontiak Melayu Majo ini merupakan rumah Besar (adat) suku Majo yang apabila ada upacara adat masih digunakan.

Tulisan ini mengidentifikasi dan mendokumentasikan rumah Melayu Majo sebagai salah satu bangunan melayu yang perlu dijaga dan dilestarikan, serta memahami bentuk dan ruang serta makna yang terkandung didalam bangunan tersebut.

\section{Kajian Pustaka: Seni Bina Melayu}

Bangunan tradisional Melayu disebut dengan Seni Bina Melayu, rumah bukan saja sebagai tempat tinggal, tetapi juga menjadi lambang kesempurnaan hidup (Effendy, 2007). Rumah merupakan ukuran apakah seorang kepala keluarga bertanggung jawab terhadap keluarganya, orang yang tidak mempunya rumah dianggap tidak memilki tangung jawab terhadap anak dan istri. Rumah tradisional Melayu yang identik dengan rumah panggung berbahan kayu memiliki kearifan lokal yang adaptif serta menyesuaikan dengan iklim dan lingkungan sekitarnya. Menurut Yuan (1987), banyaknya bukaan udara/ventilasi merupakan salah satu bentuk desain yang adaptif terhadap iklim, interior ruangan dalam yang minim partisi, peninggian elevasi rumah (bentuk panggung) untuk melancarkan ventilasi, penggunaan bahan bangunan yang tidak menyerap panas, hingga orientasi rumah barat-timur yang mereduksi sinar matahari langsung. Arsitektur tradisional Melayu melambangkan kecerdikan orang Melayu dalam beradaptasi dengan masyarakat dan habitat 
sekitarnya secara fisik dan spiritual (Rashid, 2017). Husny (dalam Rusmiawati dan Prasetyo, 2013) mengatakan, selain dipengaruhi oleh aspek iklim setempat rumah melayu juga dipengaruhi syarat agama.

Rumah juga merupakan simbol kedudukan dari orang yang tinggal di dalam rumah tersebut, ada simbol-simbol yang menegaskan derajat pemilik rumah. Jadi rumah dalam budaya Melayu merupakan sesuatu yang istimewa, dan seni membangun rumah juga merupakan hal yang tidak dapat ditinggalkan dalam kebudayaan Melayu.

\section{Tipologi Bangunan Melayu}

Tipologi rumah tradisional Melayu adalah rumah panggung atau berkolong dan memiliki tiang-tiang tinggi (Mudra, 2004). Ruangan pada rumah Melayu memiliki nama dan fungsi, tiap-tiap daerah juga memiliki penamaan yang berbeda, akan tetapi fungsinya masih sama. Rumah Melayu diberi penamaan berdasarkan bentuk atap, sebutan lain adalah berdasarkan bentuk atap dan kemiringan atap, berdasarkan pada posisi rumah terhadap jalan raya, serta sebutan berdasarkan bentuk bubungan atap. Sedangkan secara umum Firzal (2015) mengatakan untuk mengidentifikasi rumah Melayu terdapat tiga ciri fisik di dalam cara konstruksinya, yaitu: fakta bahwa rumah tersebut berbentuk panggung, bentuk atap pelana, dan finishing atap dengan gable-finials. Kassim (2017) mengatakan atap rumah melayu secara tradisional tidak hanya mencerminkan asal-usul penghuninya, tetapi juga status sosial dan keuangan mereka.

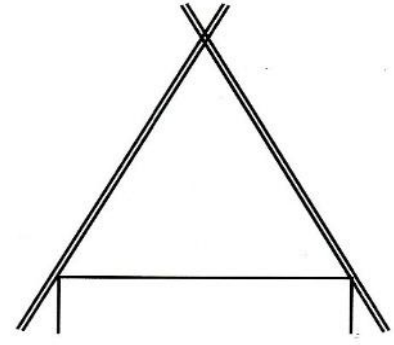

Atap Lipat Pandan

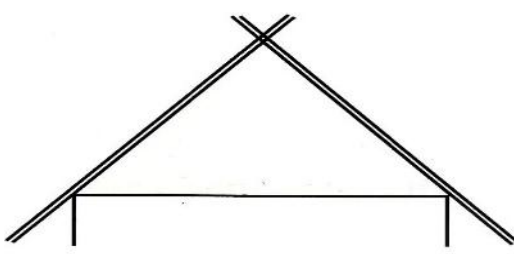

Atap Lipat Kajang

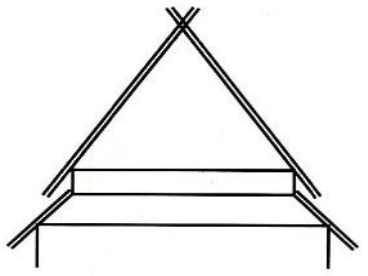

Atap Layar atau Ampar Labu

Gambar 1. Penamaan Rumah Berdasarkan Bentuk Atap

Sumber: Mudra, 2004

Susunan ruang pada rumah tradisional melayu bisa dikatakan beragam, susunan ruang tersebut tergantung kebutuhan dan perubahan yang dilakukan masyarakat setempat. Secara garis besar, Faisal (2017) mengatakan bahwa rumah orang asli ataupun rumah vernakular di sepanjang pantai timur Sumatera terdiri dari 3 (tiga) ruangan, yang memiliki fungsi yang hampir sama, namun berbeda dari penyebutannya saja. Sejalan dengan apa yang disampaikan Effendi (2014) penataan ruang rumah tradisional Melayu-Riau umumnya dipisahkan menjadi tiga bagian: selasar, rumah induk dan penaggah. Wahyuningsih dan Abu (1986) menambahkan susunan rumah melayu menjadi 4 (empat) ruangan, yaitu selasar, rumah induk, telo dan penanggah. Sedangkan Mudra (2004) membagi susunan rumah melayu menjadi 7 (tujuh) ruangan.

Tata ruang adalah karakteristik yang paling penting dari bentuk melayu karena ia lahir dari hierarki fungsi koneksi rumah dan kehidupan keluarga. DImana dalam penjelasannya Ruang dibagi antara publik, swasta, dan transisi atau semi-publik. gagasan privasi keluarga tercermin dalam bentuk dan pengaturannya (Kassim, 2017). 


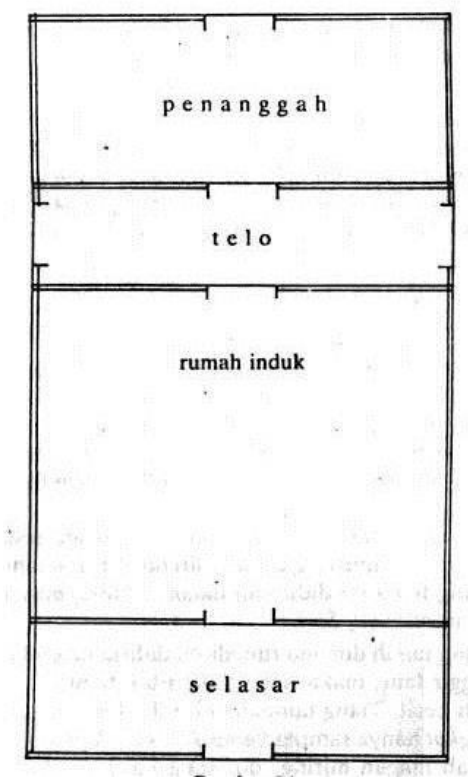

Gambar 2. Denah (Typologi) Bangunan Melayu Sumber: Wahyuningsih dan Abu, 1986

\section{Ornamen Bangunan Melayu}

Rumah melayu memiliki ornamen dan ragam hias yang kaya, bentukan ukiran dan yang sangat indah, motif-motif yang tidak hanya sebatas ukiran, namun memiliki filosofi dan makna yang dalam. Ciri unik lainnya dari rumah tradisional adalah ornamen ukiran kayu, yang kebanyakan terinspirasi oleh interpretasi flora dan fauna lokal (Firzal, 2015). Bentuk yang indah dan diukir dengan tangan yang terampil (Waterson, 1997), masing-masing motif ornamen ukiran memiliki simbolis tersendiri makna dan nilai yang telah diturunkan dari generasi ke generasi (Yuan, 1987).

Selembayung yang disebut juga Sulo Bayuang dan Tanduak Buang, adalah hiasan yang terletak bersilang pada kedua ujung perabung bangunan (Mudra, 2004). Dibawah selembayung terdapat ornamen seperti tombak terhunus, menyambung kedua ujung perabung. Sayap Layanglayang atau Sayap Layangan merupakan hiasan yang terdapat pada keempat sudut cucuran atap (Mudra, 2004). Sedangkan Lebah Bergantung, atau Lebah Begayut terdapat pada bagian bawah cucuran atap (lisplang) namun adakalanya terdapat pada anak tangga. Hiasan yang terdapat pada sepanjang perabung rumah disebut Kuda Berlari dan ada yang di sebut Sisik Naga. Selanjutnya ada yang disebut Singap, Teban Layar, Ebek, atau Bidai. Bagian ini biasanya dibuat bertingkat dan diberi hiasan yang sekaligus berfungsi sebagai ventilasi. Pada bagian yang menjorok keluar diberi lantai yang disebut Teban Layar atau Lantai alang buang atau disebut juga Undan-undan. Selain itu menurut Nazuki dan Kamrudin (2017) Pola ukiran ornament bangunan melayu diklasifikasikan menjadi dua jenis yang merupakan komponen ukiran dua dimensi dan tiga dimensi.

\section{Ragam Hias}

Efendi (2007) mengatakan bahwa motif-motif yang terdapat di daerah Riau secara garis besar bersal dari flora, seperti Kaluk Pakis, Bunga Hitan, Bunga Kundur, Tampuk manggis, Pucuk Rebung, serta yang berasal dari fauna seperti Itik Pulang Petang, Semut Beriring, Siku Keluang, dan motif dari alam seperti Bulan Sabit, Bintang-bintang, dan Awan Larat, dan lain sebagainya. Sedangkan kelompok Kaluk Pakis adalah daun-daunan dan akar-akaran. 


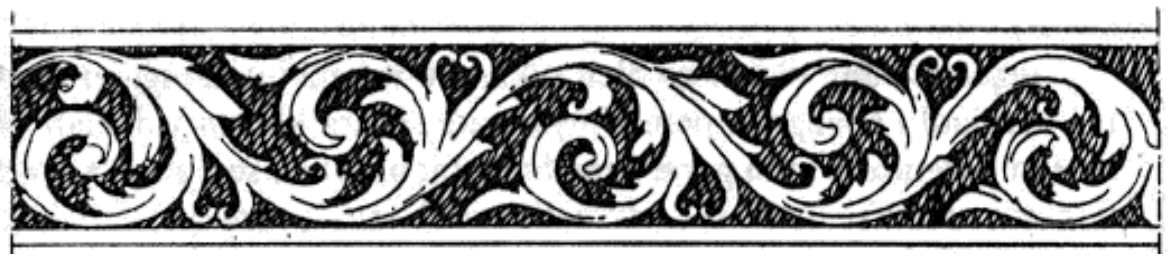

Gambar 3. Ukiran Motif Dasar Kaluk Pakis

Sumber: Wahyuningsih dan Abu, 1986

Ragam hias Bunga-bungaan yaitu, Bunga kundur, bunga melati, bunga manggis, bunga cengkih, bunga melur, bunga cina, bunga hutan, serta rangkaian bunga matahari, tampuk pinang dan roda bunga. Pucuk Rebung berbentuk segitiga dengan garis-garis lengkung dan lurus di dalamnya. Pada umumnya didalam segitiga tersebut terdapat satu garis tegak lurus yang dirangkai dengan ranting (garis-garis) melengkung ke kiri dan ke kanan. Garis-garis lengkung inilah yang membentuk pola ukiran pucuk rebung. Motif ini merupakan perumpaan dari pucuk bambu muda.

Motif Lainnya selain ragam hias yang dibahas di atas, masih ada beberapa ragam hias yang termasuk ke dalam khazanah perbendaraan Melayu. Seperti, Motif alam, Motif dari agama islam dan kepercayaan, Motif jala-jala, Terali biola dan lain-lain.

\section{Metode Penelitian: Pendekatan Kualitatif dengan Studi Kasus}

Metode penelitian yang digunakan dalam penelitian ini adalah metode penelitian kualitatif dengan pendekatan studi kasus. Studi kasus merupakan penelitian dimana peneliti menggali suatu fenomena tertentu (kasus) dalam suatu waktu dan kegiatan (program, even, proses, institusi atau kelompok sosial) serta mengumpulkan informasi secara terinci dan mendalam dengan menggunakan berbagai prosedur pengumpulan data selama periode tertentu (Creswell, 1998). Teori tentang arsitektur Melayu dan ornamen bangunan Melayu sebagai background knowledge dengan didukung informasi yang diperoleh dari sumber-sumber dan pelaku kegiatan di dalam lingkup penelitian. Objek pengamatan dalam penelitian ini adalah rumah Melayu Majo di Desa Sipungguk Kampar. Pengumpulan data melaui tinjauan pustaka dan kajian literatur serta melihat teori-teori dan konsep rumah melayu. Dilanjutkan survey lapangan untuk mengumpulkan data melalui pengamatan langsung pada obyek Rumah Melayu Majo termasuk interaksi verbal secara langsung bersama informan (pemilik rumah). Wawancara dilakukan untuk memperoleh informasi yang mendalam tentang faktor-faktor yang terhadap terbentuknya wujud fisik bentuk rumah. Selanjutnya melakukan pengolahan data dan analisis data, mengevaluasi, dan membuat sketsa, penggambaran ulang berdasarkan informasi data yang dikumpulkan untuk katagori pada objek amatan. Kemudian diakhiri dengan penyusunan hasil temuan lapangan.

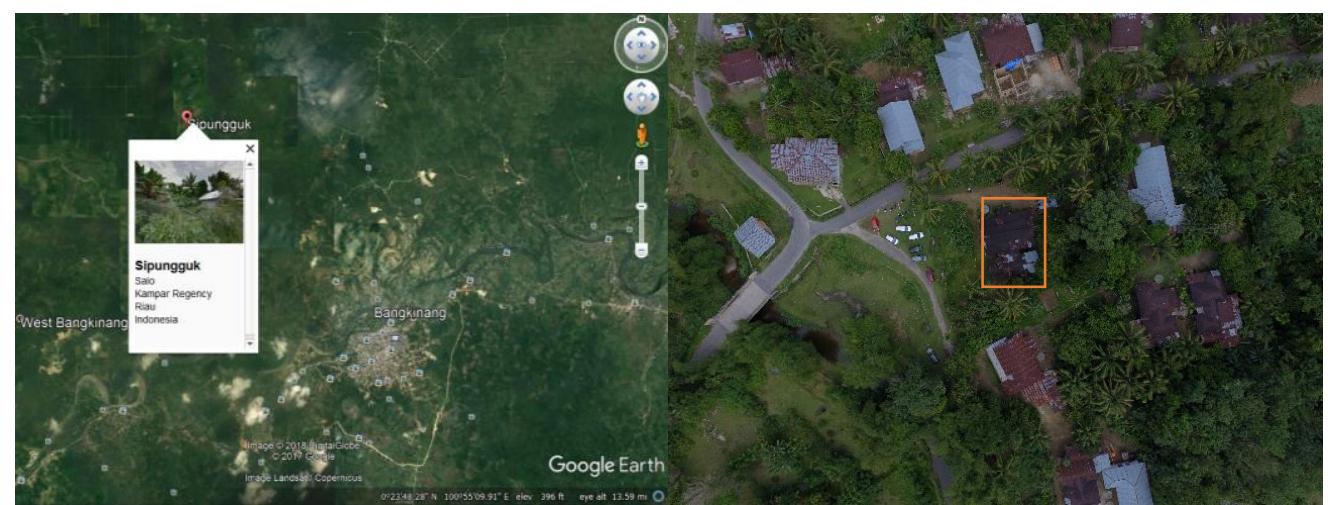

Gambar 4. Lokasi Rumah Lontiak Melayu Majo di Desa Sipungguk, Kampar, Riau Sumber: Google Earth, 2018 


\section{Hasil dan Pembahasan}

\section{Rumah Lontiak Melayu Majo}

Bangunan rumah lontiok ini adalah rumah milik bapak Zamri Yakub yang didirikan pada tahun 1959. Sebelum dilakukan pembangunan rumah ini dilakukan upacara adat, pada upacara tersebut mengorbankan 7 ekor kerbau. Secara umum rumah ini dibagi kedalam 2 (dua) masa bangunan, dimana secara garis bersar bagian pertama yaitu rumah induk terdiri dari serambi depan dan ruang tengah yang terdiri dari kamar-kamar, kemudian masa bangunan kedua yaitu dapur, terdapat penghubung rumah induk dan dapur.

Rumah ini dikenal dengan sebutan rumah Lontiok dikarenakan bentuk atapnya yang melentik ke atas pada bagian ujungnya. Atap lontiok ini memiliki filosofi akan kehidupan manusia yang ada awal dan akhirnya serta kembali kepada sang pencipta. Sedangkan pada bagian tengah perabungnya melambangkan lembah kehidupan yang terkadang penuh dengan berbagaai cobaan.

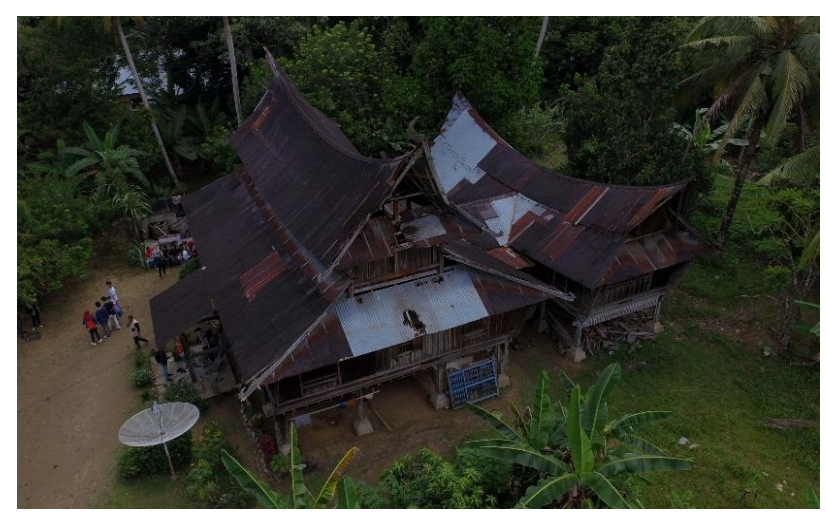

Gambar 5. Rumah Lontiak Melayu Majo

Sumber: Dokumentasi Pribadi, 2018

Serambi Depan merupakan ruang untuk tamu pria, para tetangga, para pemangku adat dan yang dituakan. Pada Seambi terdapat empat jendela setinggi bahu orang duduk. Jendela ini berfungsi sebagai sarana untuk melihat tamu yang datang. Selanjutnya ada ruang serambi tengah atau ruang rumah induk pada bagian belakang serambi depan. Pada awalnya ruang tengah tidak terdapat kamar, hanya ruangan luas yang difungsikan sebagai tempat untuk duduk-duduk. Setelah anak Pemilik rumah melangsungkan pernikahan maka dibuatlah kamar sebagai pembatasnya, kini terdapat dua buah kamar di ruang tengah.

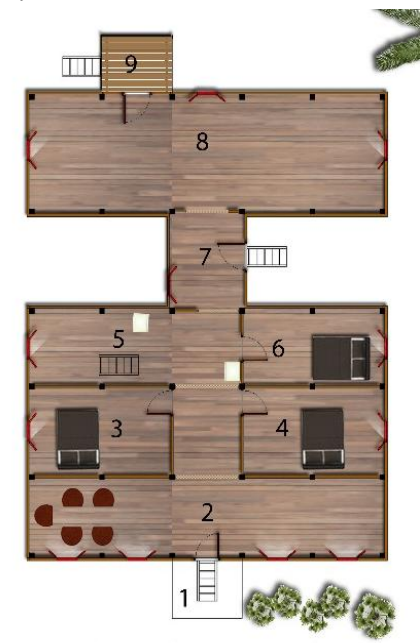

\section{keterangan}

selang depan

serambi depan

kamar utama

kamar

kamar

tangga menuju keatas

selasar/ selang samping

dapur

selang belakang

Gambar 6. Susunan Ruang Rumah Lontiak Melayu Majo

Sumber: Sketsa Pribadi, 2018 
Pada rumah melayu Majo terdapat ruangan-ruangan lain yang hampir sama tipologinya dengan rumah melayu pada umumnya, dikarenakan rumah ini bertingkat maka terdapat ruang Salang pada tinggat kedua. Ruang Salang ini terdapat di atas yang difungsikan sebagai tempat penyimpanan padi atau barang. Akses menuju ke ruangan ini menggunakan tangga yang terdapat pada ruangan tengah. Kemudian ada ruang Telo, ruang ini adalah ruang yang difungsikan untuk tempat masuknya perempuan. Dapat dikatakan bahwa penggunaan ruang ini didominasi oleh perempuan, bukan hanya oleh perempuan pemilik rumah tetapi juga digunakan untuk menerima tamu perempuan

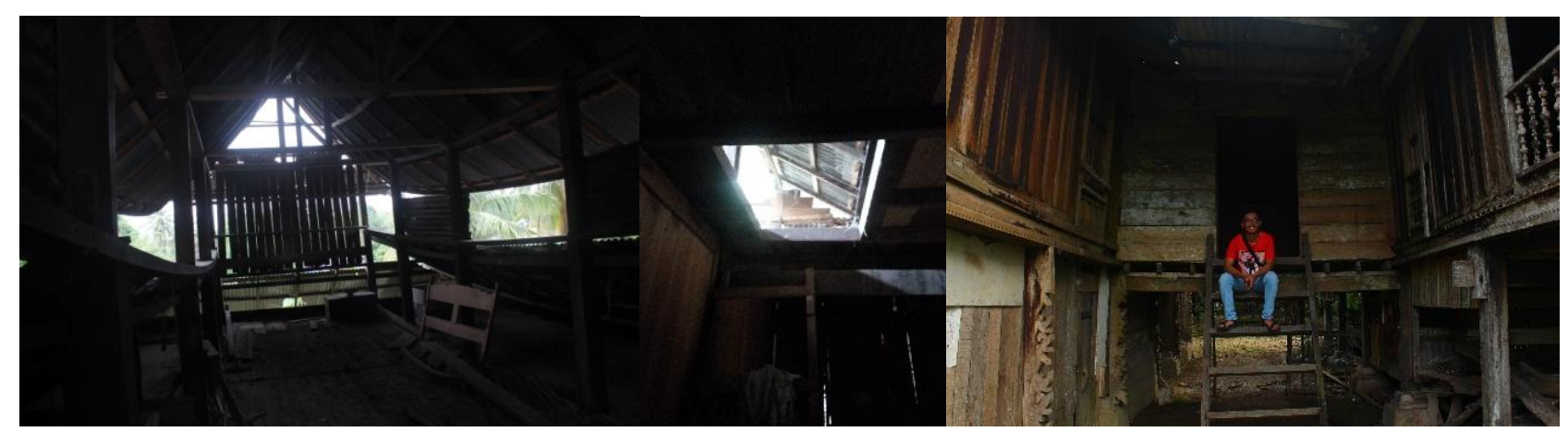

Gambar 7. Ruang Salang (kiri) dan Ruang Telo (kanan) Sumber: Dokumentasi Pribadi, 2018

Pada masa bangunan kedua digunakan sebagai Pedapuan atau Dapur, seperti pada umumnya dapur difungsikan untuk tempat memasak, tempat kaum ibu bertamu, serta ruang makan keluarga. Selangan Pinggan terdapat pada dinding dapur yang berfungsi sebagai tempat meletakkan piring yang telah dicuci. Pada ruang dapur ini juga terdapat Pelantau atau Pelantaran, ruang ini terdapat pada bagian luar dapur yang difungsikan untuk tempat mencuci piring.
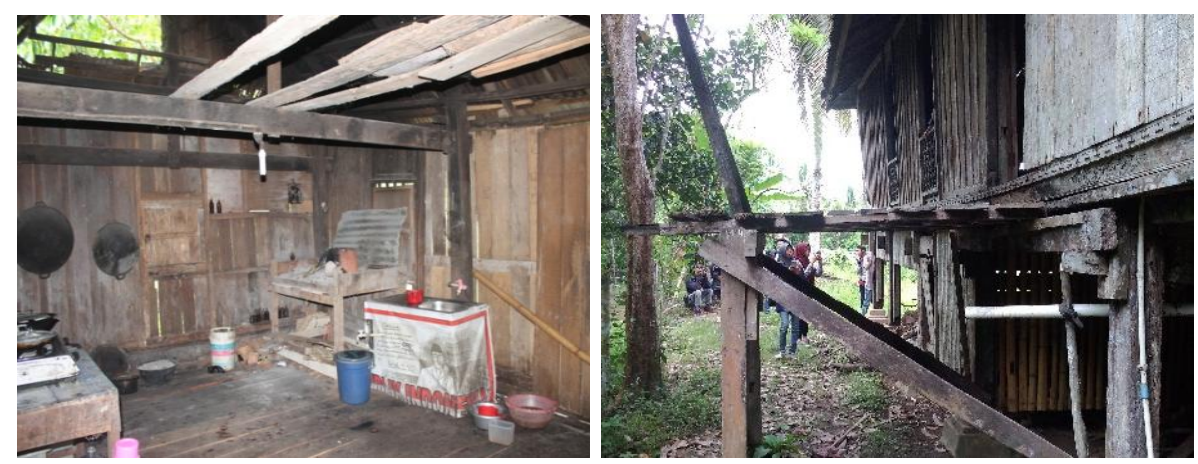

Gambar 8. Pandapuan / dapur (kiri) dan pelantau / pelantaran (kanan)

Sumber: Dokumentasi Pribadi, 2018

\section{Struktur dan Kontruksi Rumah Lontiak Melayu Majo}

Rumah melayu Majo merupakan bangunan bertipologi panggung, pada bagian pintu masuknya terdapat sebuah tangga dengan anak tangga berjumlah 5 (lima) buah. Umumnya tangga rumah ini berjumlah ganjil, hal ini dipengaruhi oleh nilai agama islam yang dianut oleh masyarakat melayu Kampar. Jumlah tiang pada bangunan ini berjumlah 38 buah, dimana 36 nya merupakan tiang utama sedangkan 2 lagi tiang pada selang depan yang berfungsi sebagai penopang atap pada tangga depan. Terdapat Umpak atau Sondi yang berfungsi sebagai podasi dari tiang-tiang tersebut. 


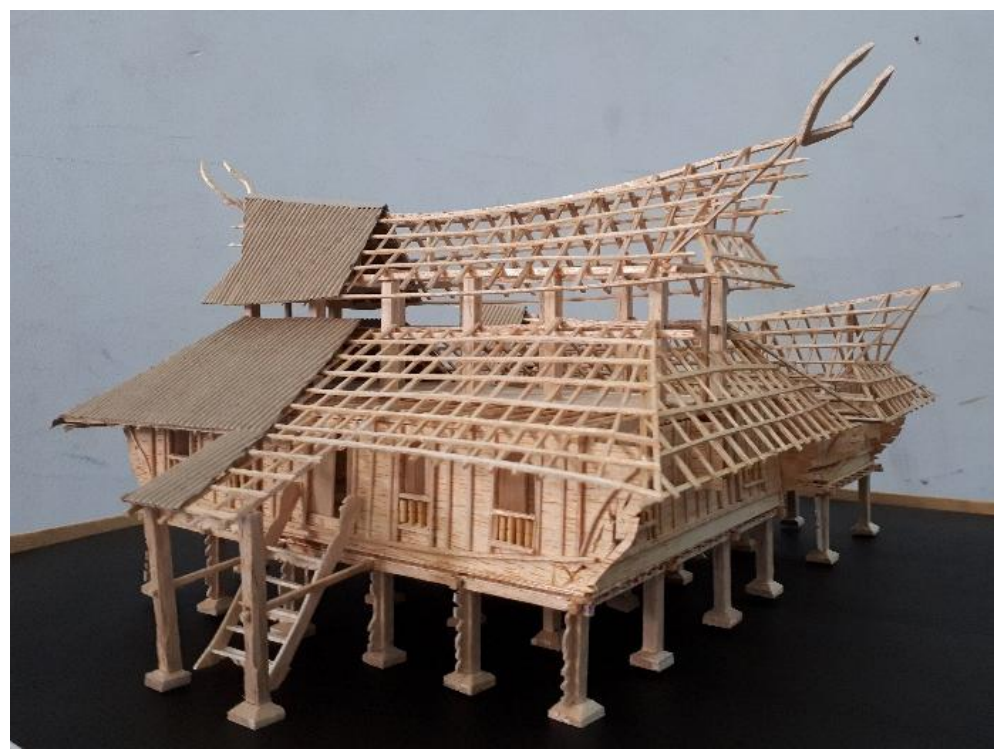

Gambar 9. Maket Struktur dan Kontruksi Rumah Lontiak Melayu Majo Sumber: Dokumentasi Pribadi, 2019

Rumah ini dikenal dengan sebutan rumah Lontiok dikarenakan bentuk atapnya yang melentik ke atas pada bagian ujungnya. Bentukan atap Lontiok memiliki filosofi bahwa kehidupan manusia akan kembali kepada sang pencipta. Kemudian bagian perabung yang cekung menandakan lembah kehidupan yang penuh lika-liku. Tangga utama menghadap ke jalan, dengan tiang tangga berbentuk persegi. Kaki tangga diberi umpak sebagai alas. Bagian atas tangga diletakkan miring ke pintu. Anak tangga berbentuk pipih. Tangga depan terletak pada pintu serambi muka dan berada pada bawah cucuran atap depan. Jumlah tiang rumah induk berjumlah 24 buah, sedangkan tiang untuk bagian dapur berjumlah 12 buah. Tiang-tiang terdiri dalam 6 baris, masing-masing baris 4 buah tiang. Sedangkan bagian dapur dngan 6 baris 2 lajur tiang. Apa yang ditemukan pada rumah Melayu Majo sama halnya denga apa yang disampaikan Zain (2017) dimana pola pada grid struktur bawah rumah Tradisional Melayu membentuk ruang - ruang dalam menciptakan suatu bangunan dengan volume struktur yang dihasilkan dapat menyesuaikan keperluan akan kebutuhan ruang.

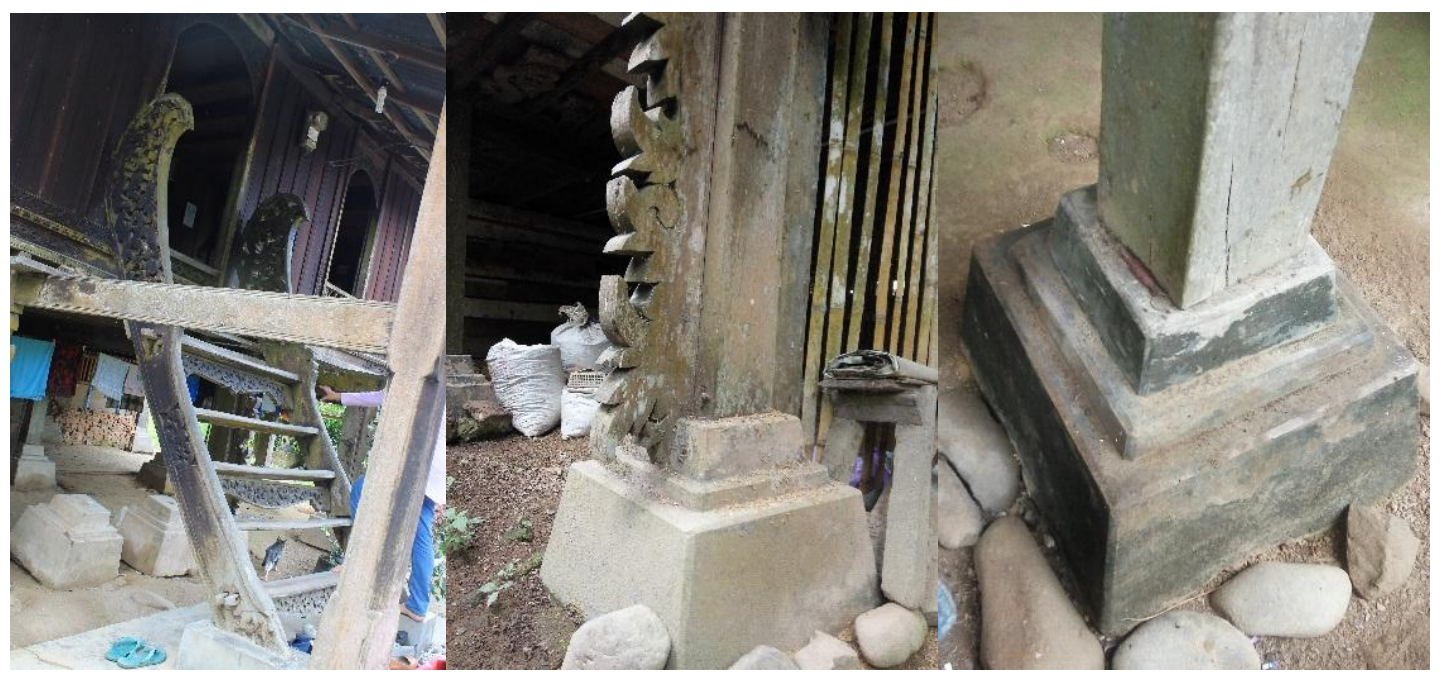

Gambar 10. Tangga (kiri) Tiang (tengah) dan Sondi atau Umpak (kanan)

Sumber: Dokumentasi Pribadi, 2018 
Penggunaan sistem pasak terlihat pada semua bagian rumah ini. Terlihat sambungansambungan kayu sebagai bagian dari sistem struktur, menjadi bagian utama dalam kontruksi rumah melayu Majo ini. Penutup struktur tersebut berupa dinding papan, pola pemasangan dinding rumah ini menggunakan pola tindih kasih. Hal ini dapat terlihat (gambar 11), dimana terdapat papan yang menindih dan papan yang ditindih, dan dipasang vertikal.

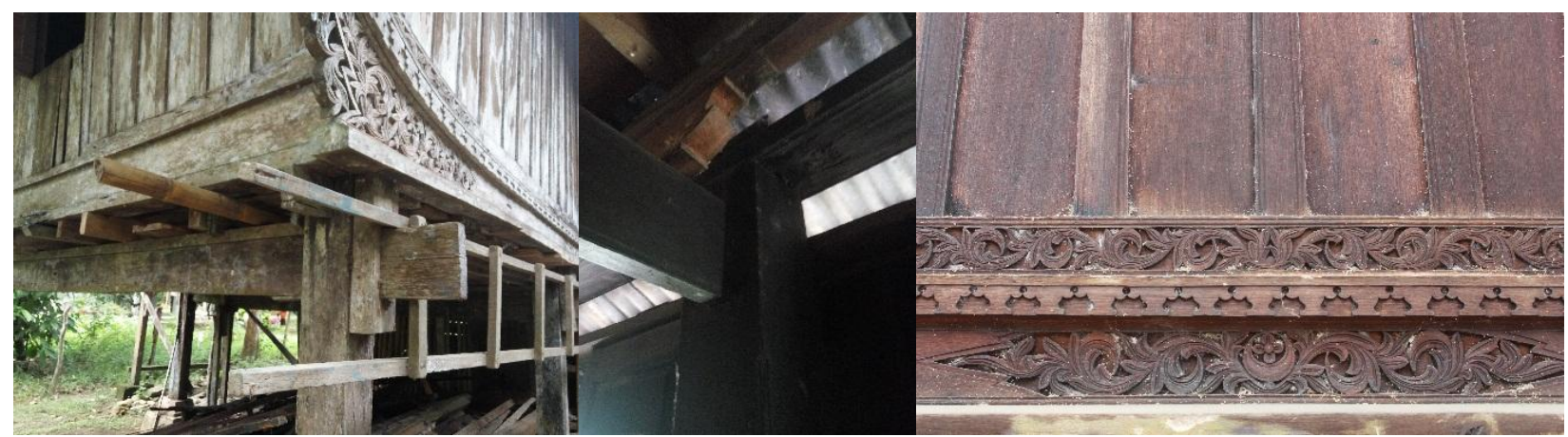

Gambar 11. Struktur pasak dan dinding tindih kasih Sumber: Dokumentasi Pribadi, 2018

Sejalan dengan apa yang disampaikan Zain dan Fajar (2014) rumah tradisional Melayu memiliki banyak jendela dan dinding padat dengan memberikan ventilasi yang baik, dan ornamen yang menarik. Jendela disebut tingkap, bentuknya menyerupai bentuk pintu namun ukuranya lebih kecil. Memiliki dua daun jendela dan terdapat motif ukiran. Pada jendela terdapat ornamen yang disebut pinang-pinang atau gasing. Samahalnya dengan pintu, jendela menggunakan Putting sebagai engselnya. Sedangkan kuncinya terbuat dari kayu yang yang pasang melintang dan disebut Pengkelang. Rumah ini terdiri dari beberapa pintu diantaranya; 1 buah pintu muka; 1 buah pintu samping; dan 1 buah pintu menuju Pelantau.

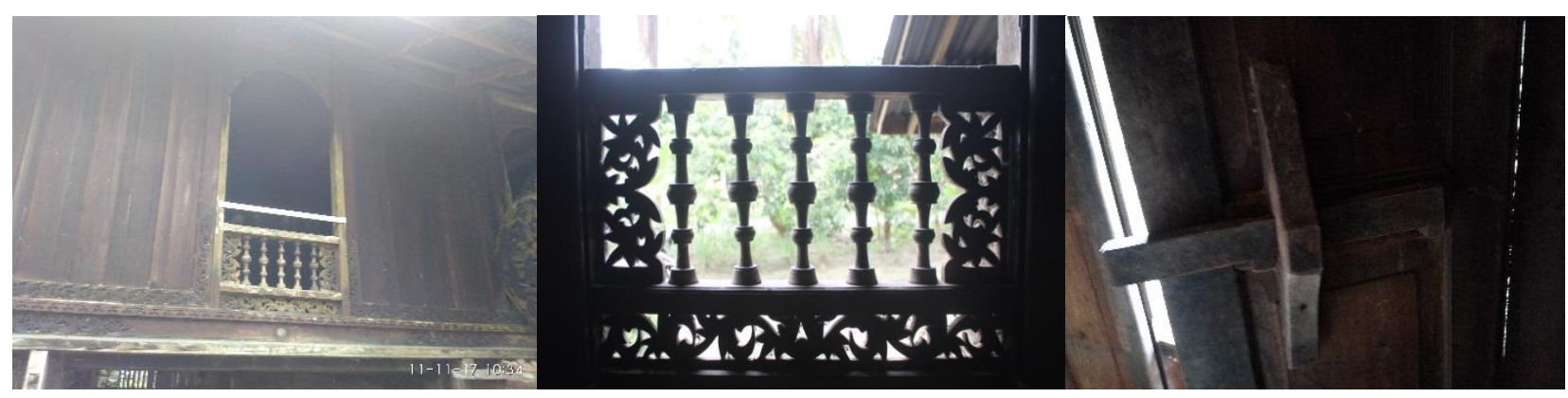

Gambar 12. Jendela (kiri), Hiasang Gasing (tengah) dan Pengkelang /pengunci jendela (kanan) Sumber: Dokumentasi Pribadi, 2018

\section{Ornamen Rumah Lontiak Melayu Majo}

Ornamen yang pertama kali terlihat pada rumah ini adalah Selembayung atau disebut juga Tanduk Buang, ornamen ini terletak bersilang pada kedua ujung perabung atap bangunan. sedangkan dibawah bawah Selembayung terdapat ornamen tambahan berbentuk mata tombak yang terhunus, yang dinamakan tombak-tombak. Selain itu, juga terdapat ornament sayap layang-layang, yang berada pada sudut cucuran atap. 


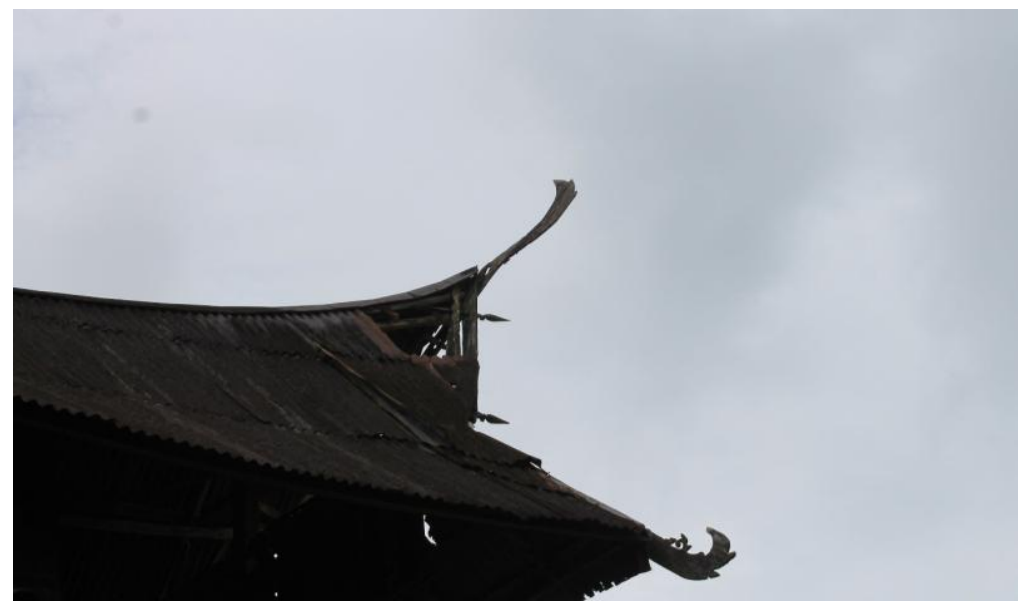

Gambar 13. Selembayung, Tombak-tombak dan Sayap layang-layang Sumber: Dokumentasi Pribadi, 2018

Seperti bangunan khas Melayu pada umumnya, rumah lontiok ini juga menggunakan banyak ukiran-ukiran di sekelilingnya, ragam ukiran yang digunakan adalah ragam flora, ukiran-ukiran tersebut tersebar pada bagian penutup atap, kaki dinding, pada bagian pintu dan jendela serta terdapat pula ukiran pada bagian tangga. Ukiran-ukiran ini mengandung makna bahwa kehidupan manusia dan alam tidak dapat dipisahkan, atau dengan kata lain menyatu dengan alam.

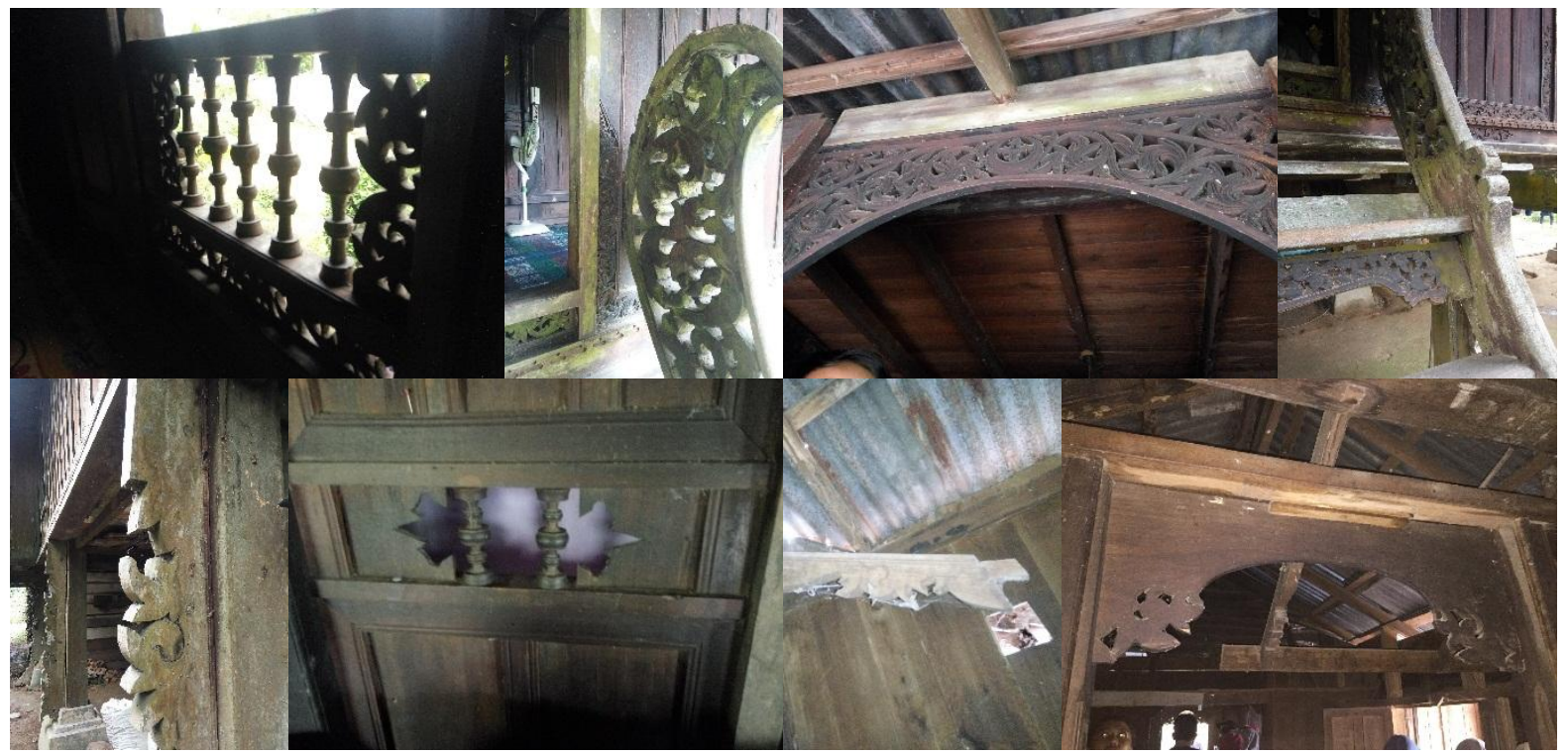

Gambar 14. Ukiran yang terdapat pada rumah Lotiak Melayu Majo

Sumber: Dokumentasi Pribadi, 2018

Ukiran-ukiran ini juga melambangkan status sosial pemilik rumah, semakin banyak dan semakin bagus ukiran-ukiran yang ada semakin tinggi status sosial pemiliknya. Ukiran pada bagian bawah dinding disebut Gando Ari, yaitu ukiran sepanjang bagian kaki dinding muka dan belakang rumah. 

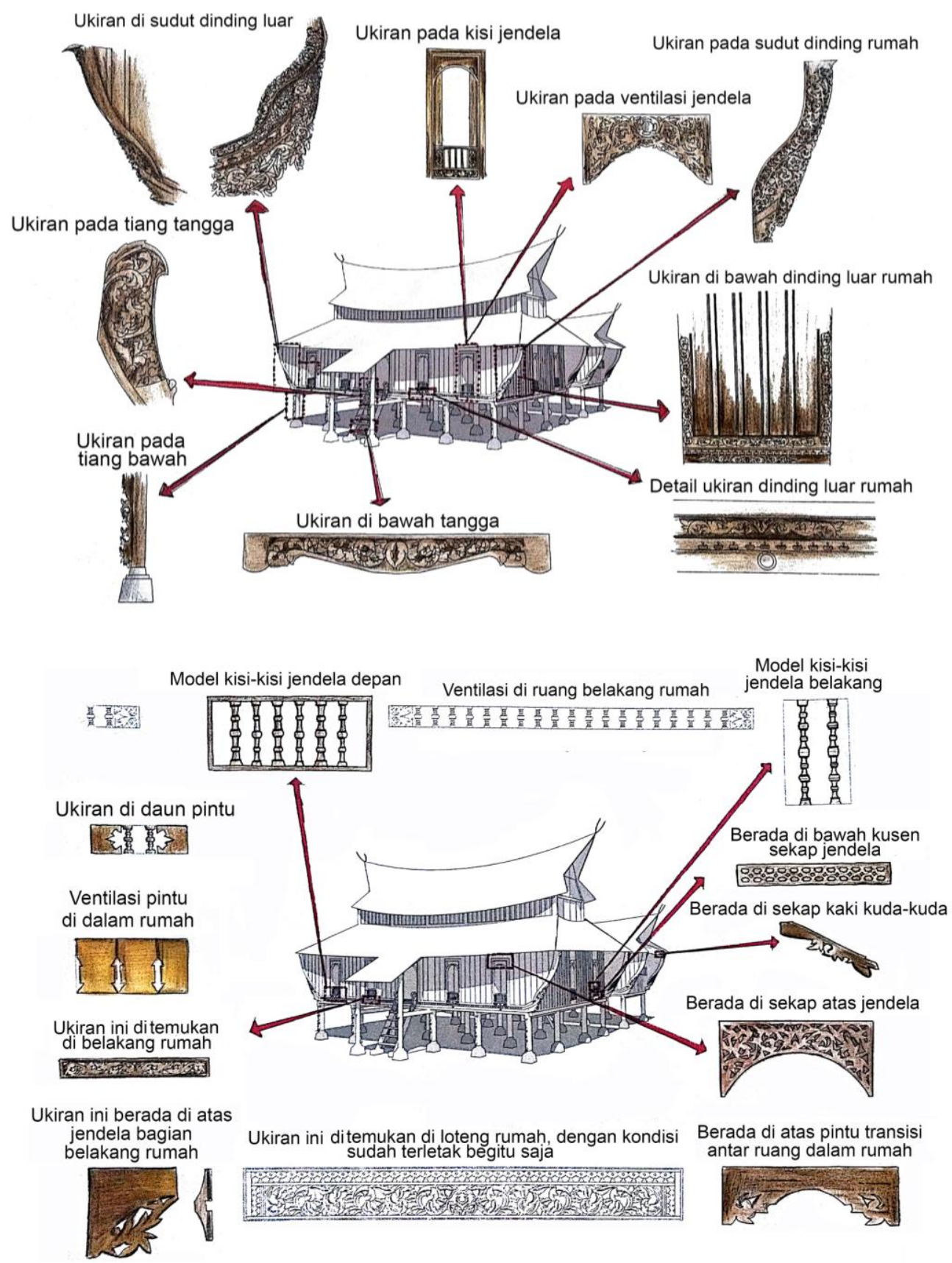

Gambar 15. Penempatan Wood Carving Pada Rumah Melayu Majo Sumber: Sketsa Pribadi, 2019

\section{Kesimpulan}

Kegiatan Pendokumentasian rumah Melayu Suku Majo yang berada di Desa Sipungguk Kabupaten Kampar ini merupakan kegiatan perekam data untuk mendapatkan data gambar existing dalam rangka menjaga dan melestarikan rumah melayu. Selain itu untuk menambah hasanah pegetahuan di bidang arsitektur, khusunya arsitektur melayu. Bangunan Rumah Adat Melayu Majo yang berada di Desa Sipungguk, Kabupaten Kampar ini merupakan salah satu bangunan yang memiliki khas dan karakter, sehingga layak untuk di dokumentasikan dan dilestarikan. Secara umum rumah ini dibagi kedalam 2 (dua) masa bangunan, dimana secara garis bersar bagian pertama yaitu rumah induk, kemudian masa bangunan kedua yaitu dapur, terdapat penghubung rumah induk dan 
dapur. Rumah melayu Majo merupakan bangunan bertipologi panggung dengan ciri khas atap Lontiak. Ornamen yang pertama kali terlihat pada rumah ini adalah Selembayung atau Tanduk Buang, terdapat pula ornamen seperti tombak terhunus yang disebut tombak-tombak serta sayap layang-layang yang terletak di setiap sudut cucuran atap. Bermacam jenis ukiran juga terdapat pada setiap sudut bangunan ini.

\section{Daftar Pustaka}

Creswell, John W. (1998). Qualitative Inquiry and Research Design: Choosing Among Five Tradition. SAGE Publications, London.

Efendi, Tenas. (2007). "Bangunan Tradisional Melayu dan Nilai Budaya Melayu" dalam Heddy Shri Ahimsa-Putra (Ed). Masyarakat Melayu dan Budaya Melayu dalam Perubahan. Hal. 597-626. Adicitra Karya Nusa, Yogyakarta.

Efendi, Tenas. (2014). Rumah, An Ode to the Malay House. Areca Books, Penang.

Faisal, Gun. (2017). Transformasi Identitas Arsitektur Vernakular Pesisir: Tinjauan Kasus Permukiman Suku Akit Di Pulau Rupat, Proseding Seminar Nasional II Arsitektur USU. Medan: Universitas Sumatera Utara.

Firzal, Yohannes. (2015). Reconstructing SocioCultural Identity: Malay Culture and Architecture in Pekanbaru, Indonesia, Ph.D. dissertation, Newcastle University, Newcastle.

Husny, M. L. (1976). Bentuk Rumah Tradisi Melayu. B.P. Husni, Medan.

J. K. Shireen, A. M. Nor Hanita and N. M. Nawawi. (2017). The Resilience of Tradition: Malay Allusions in Contemporary Architecture. Areca Books, Penang.

Moleong, Lexy J. (2011). Metode Penelitian Kualitatif. Remaja Rosdakarya, Bandung.

Mudra, Mahyudin Al. (2004). Rumah Melayu: Memangku Adat Menjemput Zaman. Adi Cita Karya Nusa, Yogyakarta.

Nazuki, Siti Najwa dan Kamarudin, Zumahiran. (2017). Techniques of wood carving applied in the architectural elements of malay vernacular buildings. Journal of Built Environment, Technology and Engineering Vol. 2, Hal. 198202.

Rashid, Mohd Sabrizaa B. Abd. (2017). Rumah Kutai: Documentation of Memories. Institut Darul Ridzuan, Malaysia.

Rumiawati, Asnah dan Prasetyo, Yuri Hermawan. (2013). "Identification Typology of Architecture Traditional Malay Houses in Langkat District and Its Changes". Jurnal Permukiman, Vol. 8, No. 2, Hal. 78-88.

Wahyuningsih dan Abu, R. (1986). Arstektur Traditional Daerah Riau. Depdikbud Provinsi Riau, Pekanbaru.

Waterson, Rexona. (1997). The Living House: An Anthropology of Architecture in South-East Asia. Thames and Hudson, London.

Yuan, L.J. (1987). The Malay House: Rediscovering Malaysia's Indigenous Shelter System. Institut Masyarakat, Pulau Pinang, Malaysia.

Zain, Zairin dan Fajar, Indra Wahyu. (2014). "Disain Struktural Dalam Perspektif Kearifan Lokal (Local Wisdom Perspective) pada Rumah Tradisional Melayu di Kota Sambas Kalimantan Barat”. Langkau Betang, Vol. 1, No. 2, Hal. 1729.

Zain, Zairin. (2017). "Identifikasi Pola Struktur Rumah Tinggal, Studi Kasus: Arsitektur Tradisional Melayu Di Kota Pontianak”. Langkau Betang, Vol. 4, No. 1, Hal. 44-66. 